\title{
Nuclear receptor ERRa and transcription factor ERG form a reciprocal loop in the regulation of TMPRSS2:ERG fusion gene in prostate cancer
}

\author{
Zhenyu $\mathrm{Xu}^{1,2} \cdot$ Yuliang Wang ${ }^{2} \cdot$ Zhan Gang Xiao ${ }^{2,3} \cdot$ Chang Zou ${ }^{2,4} \cdot$ Xian Zhang $^{1} \cdot$ Zhu Wang $^{2} \cdot$ Dinglan $\mathrm{Wu}^{2} \cdot$ \\ Shan $\mathrm{Yu}^{2} \cdot$ Franky Leung $\mathrm{Chan}^{2}$
}

Received: 18 November 2017 / Revised: 17 May 2018 / Accepted: 19 June 2018 / Published online: 24 July 2018

(c) The Author(s) 2018. This article is published with open access

\begin{abstract}
The TMPRSS2:ERG (T:E) fusion gene is generally believed to be mainly regulated by the activated androgen receptor (AR) signaling in androgen-dependent prostate cancer. However, its persistent expression in castration-resistant and neuroendocrine prostate cancers implies that other transcription factors might also regulate its expression. Here, we showed that up-regulation of nuclear receptor estrogen-related receptor alpha $(E R R \alpha)$ was closely associated with the oncogenic transcription factor ERG expression in prostate cancer, and their increased coexpression patterns were closely associated with high Gleason scores and metastasis in patients. Both ERR $\alpha$ and ERG exhibited a positive expression correlation in a castration-resistant prostate cancer (CRPC) xenograft model VCaP-CRPC. We showed that ERR $\alpha$ could directly transactivate T:E fusion gene in both AR-positive and -negative prostate cancer cells via both ERR-binding elementand AR-binding element-dependent manners. Ectopic T:E expression under ERR $\alpha$ regulation could promote both in vitro invasion and in vivo metastasis capacities of AR-negative prostatic cells. Intriguingly, ERG expressed by the T:E fusion could also transactivate the ERR $\alpha$ (ESRRA) gene. Hereby, ERR $\alpha$ and ERG can synergistically regulate each other and form a reciprocal regulatory loop to promote the advanced growth of prostate cancer. Inhibition of ERR $\alpha$ activity by ERR $\alpha$ inverse agonist could suppress T:E expression in prostate cancer cells, implicating that targeting ERR $\alpha$ could be a potential therapeutic strategy for treating the aggressive T:E-positive prostate cancer.
\end{abstract}

These authors contributed equally: Zhenyu Xu, Yuliang Wang, Zhan Gang Xiao, Chang Zou

Electronic supplementary material The online version of this article (https://doi.org/10.1038/s41388-018-0409-7) contains supplementary material, which is available to authorized users.

Shan $\mathrm{Yu}$

yushan771@hotmail.com

$\triangle$ Franky Leung Chan

franky-chan@cuhk.edu.hk

1 Department of Pharmacy, Yijishan Affiliated Hospital, Wannan Medical College, Wuhu, Anhui, China

2 School of Biomedical Sciences, Faculty of Medicine, The Chinese University of Hong Kong, Hong Kong, China

3 Department of Pharmacology, Southwest Medical University, Luzhou, China

4 Clinical Medical Research Center, Shenzhen People's Hospital, Second Clinical Medical College, Jinan University, Shenzhen, China

\section{Introduction}

The breakthrough discovery of fusion genes formed by recurrent chromosomal rearrangements in prostate cancer in past decade contributes significantly to our current conceptual understanding on the significance of androgen signaling in prostate carcinogenesis [1], and also makes considerable impact on the early diagnosis, prognosis, and potential therapeutic management of this cancer $[2,3]$.

These recurrent fusion genes prevalent in prostate cancer are formed by fusion of the promoter and $5^{\prime}$-untranslated region (UTR, exon 1 or 2) of the androgen-regulated prostate-specific transmembrane protease serine 2 gene (TMPRSS2) with the translated regions of members of erythroblastosis virus E26 transforming sequence (ETS) family of transcription factors, ERG and ETV1 [1]. The consequence of these rearrangements results in pathogenic overexpression of ETS transcription factors and activation of transcriptional programs in an androgen-dependent manner, driving the oncogenic progression of prostate 
cancer. Subsequently, more fusion genes are identified in prostate cancer, involving additional androgen-responsive 5'-partners and other ETS and non-ETS members [4]. Among these fusion genes, TMPRSS2:ERG (T:E) fusion is the most dominant rearrangement and prevalent in majority of prostate cancer patients (40-70\%) [5-8]. Association studies show that $\mathrm{T}: \mathrm{E}$ fusion-positive prostate cancer patients present more aggressive clinical phenotypes, in term of higher tumor grade and metastasis potential, progression to androgen-independence, shorter survival and unfavorable prognosis [5, 9-13]. Clinical and preclinical studies demonstrate that $\mathrm{T}: \mathrm{E}$ fusion is detected in premalignant prostatic intraepithial neoplasia (PIN) lesions [9] and targeted in vivo expression of ERG can induce PIN lesions in transgenic mouse prostate [14], suggesting that ERG plays a casual role in prostate cancer initiation. Thus, $\mathrm{T}: \mathrm{E}$ fusion or $E R G$ is regarded as a key oncogene in prostate cancer [15].

Since most prostate cancer-prevalent fusion genes are formed by the fusion with the androgen-responsive promoter region of the androgen-activated genes (e.g., TMPRSS2 and SLC45A3), it is thus generally regarded that these fusion genes are mainly regulated by androgen receptor (AR) [1] and their oncogenic activation or overexpression is attributed to the activation of AR signaling in androgen-dependent prostate cancer. However, these fusion genes or ETS members are also expressed in androgenindependent and AR-negative prostate cancer xenograft tumors [16] and cell lines (e.g., NCI-H660) [17], metastatic androgen-independent prostate cancer [12], castrationrelapse prostate cancer [18], neuroendocrine prostate carcinoma $[19,20]$, and also patient-derived prostate cancer stem cells [21]. It still remains puzzling how these androgen-responsive fusion genes are transcriptionally regulated in androgen-independent or AR-negative prostate cancer cells. These puzzled observations also implicate that these fusion genes may bypass the AR regulation in advanced prostate cancer, and also these fusion genespositive patients are susceptible to evolve into therapyresistant and androgen-independent metastatic disease.

Previously, a genome-wide gene expression study on T:E fusion-positive prostate cancer samples performed in two prostate cancer cohorts identifies a specific T:E fusion gene signature that is associated with estrogen receptor (ER) signaling and also the T:E fusion expression could be modulated by ER ligands in AR-negative NCI-H660 cells, implying that the T:E expression can be regulated by an ERdependent mechanism [22]. In addition, an in vitro study shows that the T:E expression in AR-positive VCaP cells can be induced by vitamin D receptor ligands [23]. Based on these limited indirect studies, it suggests that besides $\mathrm{AR}$, other nuclear receptors or transcription factors could also regulate the T:E fusion gene in prostate cancer.
Estrogen-related receptor alpha (ERR $\alpha, \mathrm{NR} 3 \mathrm{~B} 1$, and ESRRA) is a ligand-independent orphan member of the nuclear receptor superfamily. Studies in past decades indicate that together with its coactivator PGC- $1 \alpha$, ERR $\alpha$ functions as a key transcriptional regulator of energy homeostasis and mitochondrial functions [24]. ERR $\alpha$ displays an increased expression pattern in hyperplastic prostates and advanced prostate cancer [25], and is also implicated as a negative prognostic predictor for prostate cancer [26]. Our recent study shows that ERR $\alpha$ promotes the hypoxic growth adaptation of prostate cancer cells via a mechanism of direct interaction with HIF- $1 \alpha$ and augmentation of HIF-1 signaling [27]. An in vivo study on intraosseous prostate cancer xenograft model shows that ERR $\alpha$ promotes the metastatic growth of prostate cancer lesions in bone via its modulation of stromal microenvironment [28].

In this study, we uncovered a reciprocal regulatory loop between ERR $\alpha$ and ERG that can promote synergistically the advanced progression of prostate cancer in an ARindependent manner, and suppression of T:E/ETS fusion genes via ERR $\alpha$ targeting could be a potential therapeutic strategy for prostate cancer.

\section{Results}

\section{Both ERRa and ERG show up-regulation and also a positive correlation in advanced prostate cancer}

In order to elucidate whether increased expressions of ERR $\alpha$ and ERG expressed by the T:E fusion gene would play a role in the advanced progression of prostate cancer, we analyzed the expression profiles of ERR $\alpha$ and ERG in clinical prostate tumor tissues and their association with the tumor grade and metastasis of patients using the cancer genomic datasets from the Cancer Genome Atlas. Analysis of RNA-seq data from 205 prostate cancer patients and 42 normal male individuals totally showed that the mRNA levels of both ERR $\alpha$ and ERG displayed significant higher expressions in tumor tissues as compared to that in normal prostatic tissues (Fig. 1a, b). Analysis also showed that both ERR $\alpha$ and ERG manifested a positive expression correlation in prostate cancer (Fig. 1c). Further analysis of the association between ERR $\alpha$ and ERG expressions in $\mathrm{AR}^{\text {low }}$ and $\mathrm{AR}^{\text {high }}$ subsets of prostate cancer patients in the same datasets revealed that both ERR $\alpha$ and ERG exhibited a positive correlation in both subsets of patients (Supplementary Fig. S1a, b). Expression analysis showed that increased ERR $\alpha$ expressions exhibited a significant positive correlation with the Gleason scores in ERG-positive but not ERG-negative prostate cancer patients and higher ERR $\alpha$ was also shown in metastatic prostate cancer tissues 

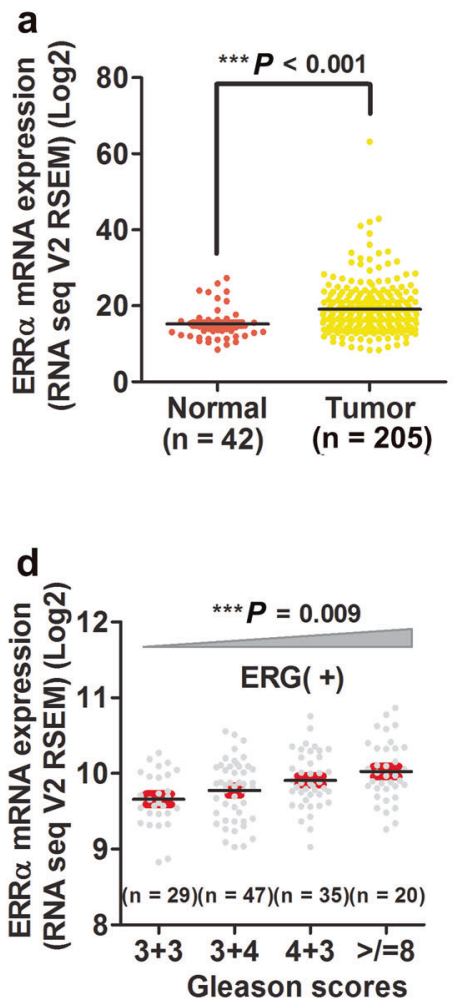

b

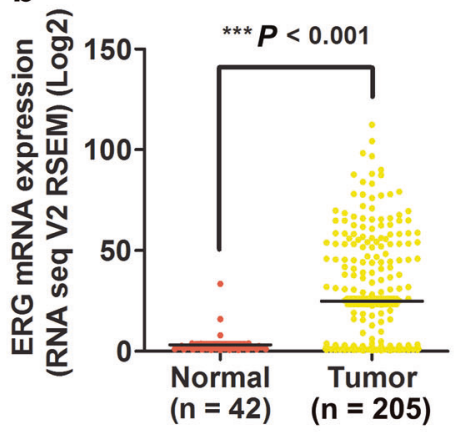

e

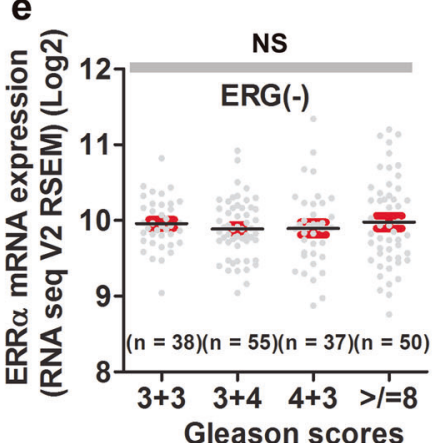

C

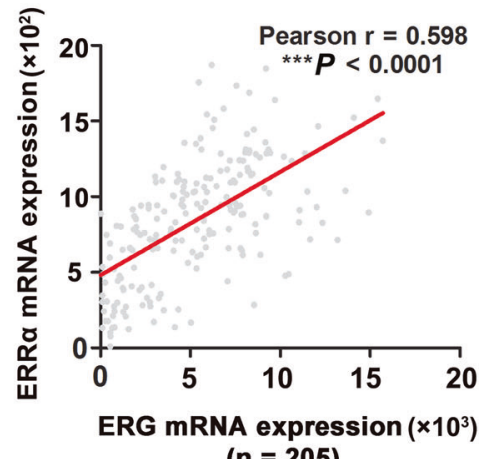

( $n=205)$

f

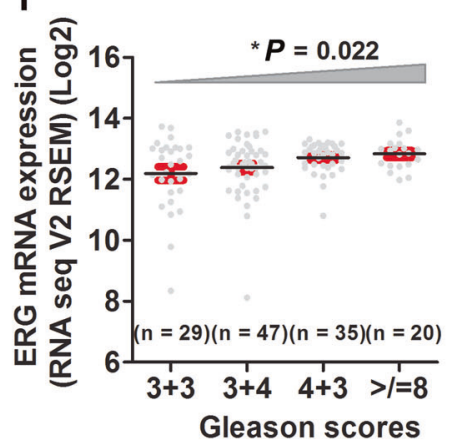

Fig. 1 Increased expressions of ERR $\alpha$ and ERG are correlated with advanced stage of prostate cancer. (a and $\mathbf{b}$ ) Expression profiles of ERR $\alpha$ and ERG as revealed from RNA-seq datasets from cohorts of prostate cancer patients. Both ERR $\alpha$ and ERG exhibited significant higher expression patterns in prostate tumor tissues $(n=205)$ than normal prostatic tissues $(n=42)$, as revealed from RNA-seq datasets from the Cancer Genome Atlas. The genomic profile information on the samples is available from the cBioPortal website (http://www. cbioportal.org/). ${ }^{* * * *} P<0.001$ versus normal prostate. (c) Pearson correlation and linear regression analysis between ERR $\alpha$ and ERG

(Fig. 1d, e; Supplementary Fig. S1c), and associated with shorter survival of prostate cancer patients [26]. Similarly, a statistically significant positive correlation was demonstrated between elevated ERG expression and the Gleason scores in cancer patients (Fig. 1f). Together, these results showed that up-regulation of both ERR $\alpha$ and ERG was positively correlated with the Gleason scores and metastasis in prostate cancer tissues.

\section{Castration-relapse xenograft tumors exhibits increased expressions of ERRa and ERG}

In order to elucidate the expression correlation between $\mathrm{ERR} \alpha$ and ERG in the progression of castration-resistant prostate cancer (CRPC), we established a CRPC xenograft tumor model VCaP-CRPC based on the castration-relapse growth of AR- and T:E-positive VCaP cells (Fig. 2a). Analysis of ERR $\alpha$ and ERG expressions in VCaP-CRPC tumor biopsies revealed that mRNA and proteins levels of both ERR $\alpha$ and ERG declined at fourth day postcastration expressions in primary prostate cancer samples $(n=205)$. Results showed that mRNA levels of ERR $\alpha$ and ERG displayed a positive correlation in prostate cancer samples. Relative Pearson correlation coefficient $r=0.598, P<0.0001$. (d and e) mRNA expressions of ERR $\alpha$ exhibited statistically significant positive correlation with the Gleason scores in ERG-positive but not in ERG-negative prostate cancer patients. NS nonsignificant. (f) mRNA expression of ERG exhibited statistically significant positive correlation with Gleason scores in prostate tumor tissues

but their levels rebounded significantly in castration-relapse xenograft tumors at levels higher than precastration (Fig. $2 \mathrm{~b}, \mathrm{c})$. We also established an androgen deprivationresistant VCaP-CRPC cell line derived from the VCaPCRPC xenograft tumors. Expression analyses showed that similar to VCaP-CRPC tumors, VCaP-CRCP cells exhibited significant higher endogenous expression levels of ERR $\alpha$ and ERG as compared to their parental VCaP cells (Fig. 2d). These results suggest that both ERR $\alpha$ and ERG exhibit an apparent positive expression correlation in CRPC xenograft tumors and their enhanced coexpressions may play a role in the CRPC.

\section{$T: E$ fusion gene is positively regulated by ERRa in prostate cancer cells independent of their AR expression status}

In order to demonstrate whether the $\mathrm{T}$ :E fusion could be regulated by $E R R \alpha$, we examined the effects of suppression of $\operatorname{ERR} \alpha$ activity or its overexpression in two prostate 

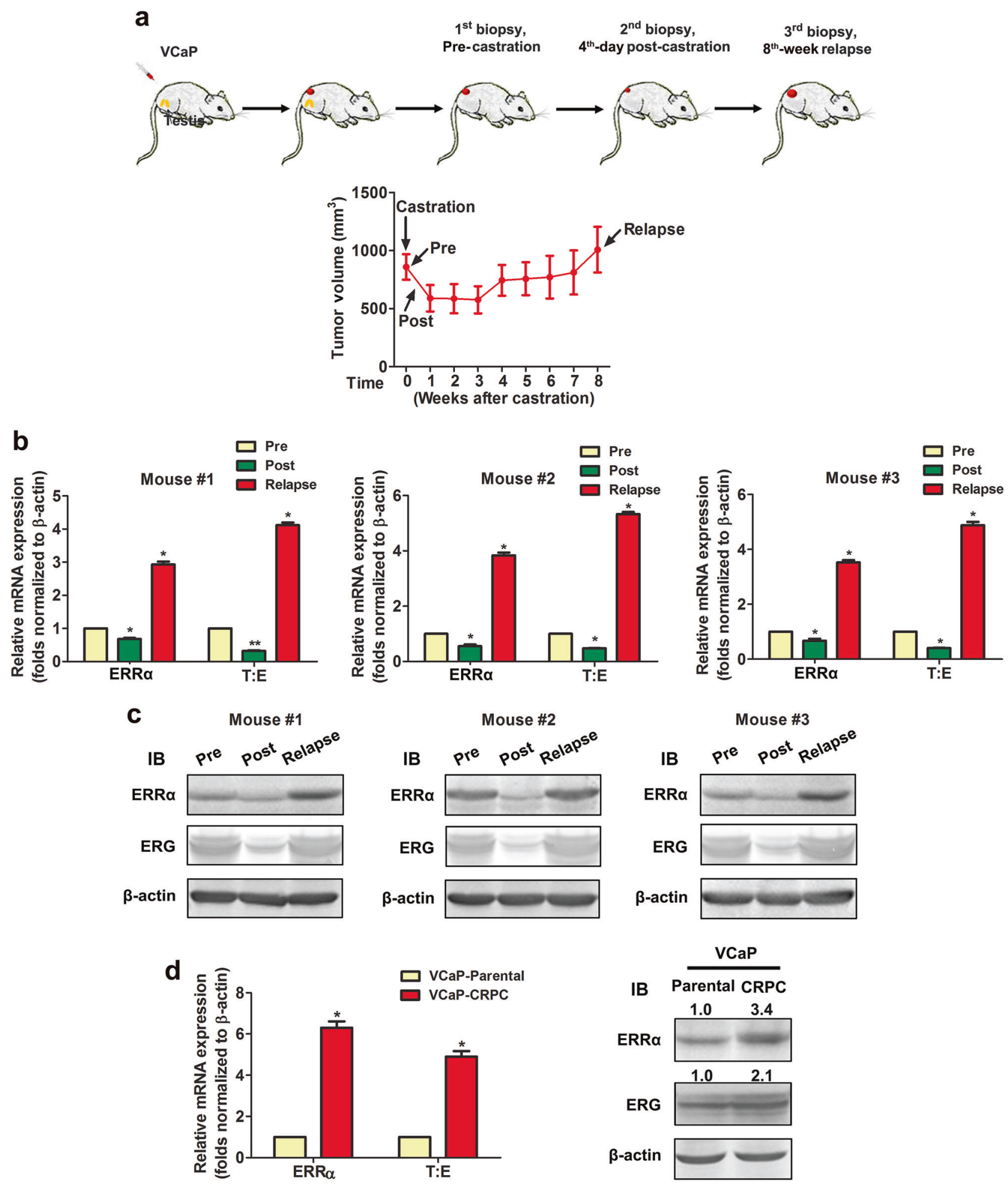

cancer cell lines, $\mathrm{VCaP}$ and NCI-H660, both harbor the T:E fusion gene and express T:E transcripts and ERG protein [1, 29]. In vitro treatment with an ERR $\alpha$-selective inverse agonist XCT790 showed that XCT790 could dosedependently suppress both the mRNA and protein levels of fusion ERG in AR-positive VCaP cells (Fig. 3a, b).
Treatment with low-dose XCT790 $(1 \mu \mathrm{M})$ could also decrease the mRNA and protein levels of fusion ERG in $\mathrm{VCaP}$ cells in a time-dependent manner (Supplementary Fig. S2a, b). However, the XCT790-induced protein reduction of ERR $\alpha$ in $\mathrm{VCaP}$ cells could be prevented by a proteasome inhibitor MG132 (Supplementary Fig. S2c), 
Fig. 2 Both ERR $\alpha$ and ERG exhibit a positive increased expression correlation in VCaP-CRPC castration-resistant xenograft tumors. a VCaP-CRPC xenograft model. Upper panel: schematic diagram shows the growth progression of VCaP xenograft tumors in castrated host mice and time-points of tumor biopsies performed. Lower panel: growth curve of $\mathrm{VCaP}$ xenograft tumors in intact host mice (with tumor sizes of $1 \mathrm{~cm}^{3}$ at precastration; Pre), fourth day postcastration (Post) and relapse at eighth week postcastration (Relapse) $(n=5)$. b RT-qPCR analysis of ERR $\alpha$ and T:E fusion gene and (c) immunoblots of ERR $\alpha$ and ERG expressed in VCaP-CRPC xenograft tumors. mRNA and protein levels of both ERR $\alpha$ and ERG expressed by $\mathrm{T}: \mathrm{E}$ fusion dropped significantly at fourth day postcastration and rebounded significantly in relapsed tumors. d RT-qPCR and immunoblot analyses of ERR $\alpha$ and T:E (ERG) in VCaP-CRPC xenograftsderived cell subline. Both ERR $\alpha$ and $\mathrm{T}: \mathrm{E} / \mathrm{ERG}$ expressed at significant higher levels in VCaP-CRPC cells as compared to their parental $\mathrm{VCaP}$ cells. ${ }^{*} P<0.01$ versus precastration $\mathrm{VCaP}$ tumors or parental $\mathrm{VCaP}$ cells. All data are presented as mean \pm SEM and obtained from three independent experiments suggesting that such $\operatorname{ERR} \alpha$ reduction was mediated by an enhanced proteasomal degradation mechanism as similarly reported in MCF7 breast cancer cells [30]. Similarly, transient ERR $\alpha$ knockdown could significantly decrease both the mRNA and protein levels of fusion ERG in VCaPshERR $\alpha$ transduced cells (Fig. 3c, d). Suppression of ERR $\alpha$ by either XCT790 or shERR $\alpha$ could significantly diminish the mRNA levels of multiple ERG-responsive target genes, including CRISP3, MMP1, PLAIA, and PLAT (Fig. 3e, f), suggesting that ERG-mediated signaling was restrained by $\mathrm{ERR} \alpha$ suppression. ERR $\alpha$ knockdown also suppressed the expressions of ERR $\alpha$ targets in both $\mathrm{VCaP}$ and LNCaP cells (Supplementary Fig. S3a, b). Since another ERR isoform $\mathrm{ERR} \gamma$ shares certain overlapping functions with $\mathrm{ERR} \alpha$ in metabolic reprogramming in cancer cells [31], we then
Fig. 3 Suppression of ERR $\alpha$ reduces T:E fusion or ERG expression and ERG-mediated signaling in AR-positive $\mathrm{VCaP}$ cells. (a, c) mRNA and $(\mathbf{b}, \mathbf{d})$ protein expressions of $\mathrm{T}: \mathrm{E}$ fusion/ERG in $\mathrm{VCaP}$ cells upon XCT790 treatment or ERR $\alpha$ knockdown by shRNA. Both mRNA and protein levels of T:E fusion/ERG were significantly reduced by XCT790 treatment in a dose-dependent manner $(1-20 \mu \mathrm{M})$ and also shERR $\alpha$. (e, f) mRNA levels of ERGresponsive targets were significantly suppressed by either XCT790 or shERR $\alpha .{ }^{*} P<$ $0.05 ;{ }^{* *} P<0.01$ versus vehicle treatment or Scramble shRNA transfection
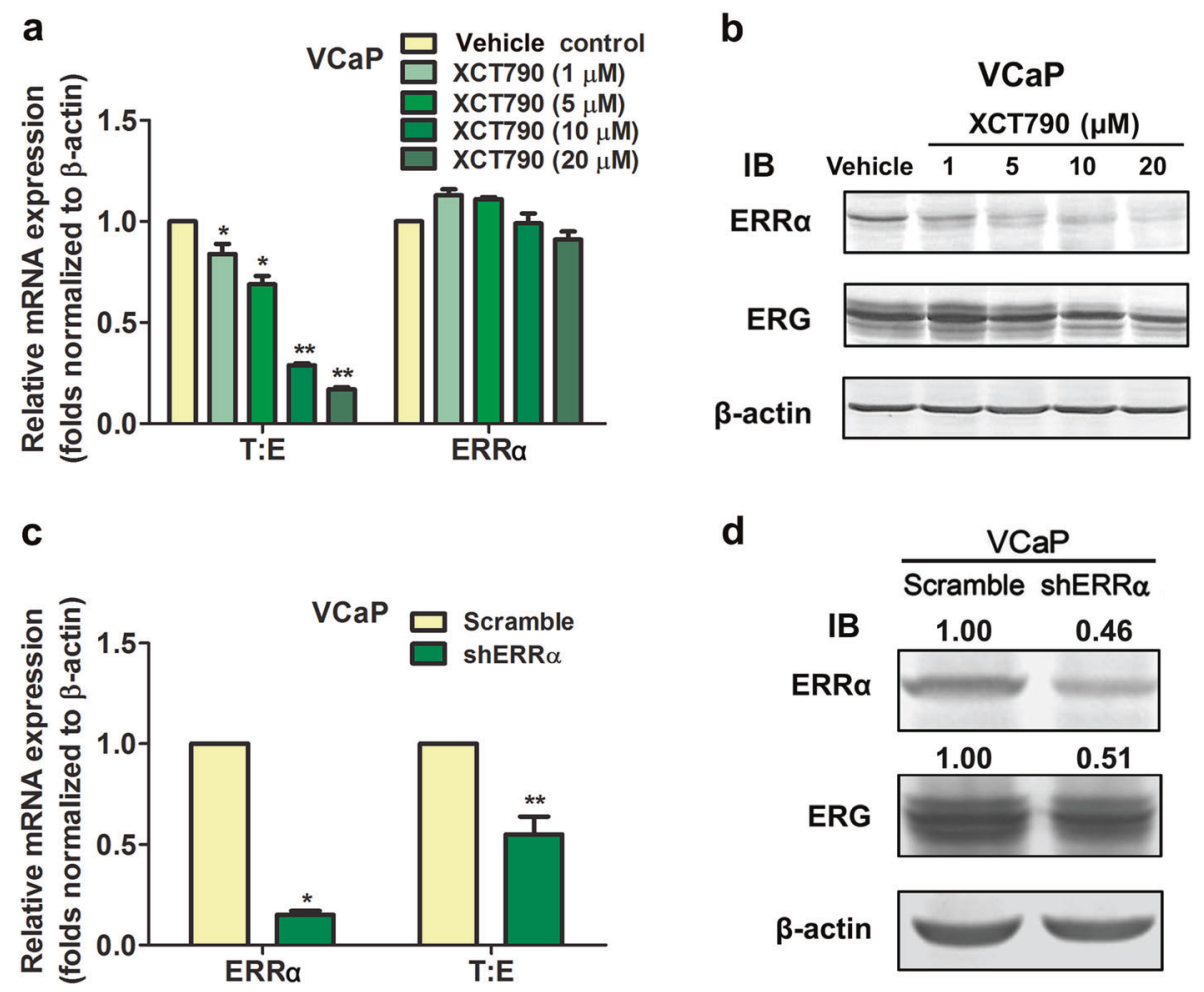

d
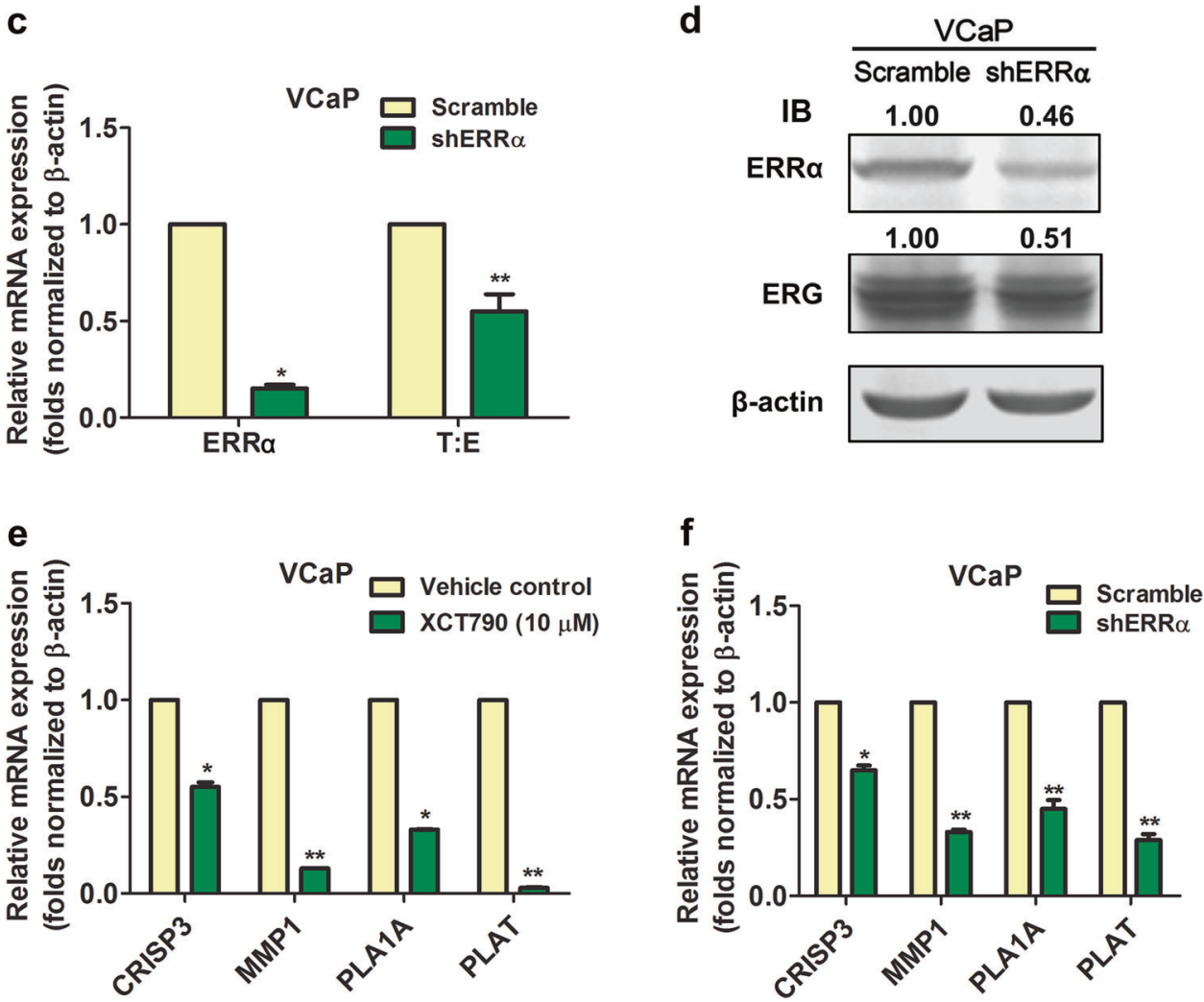
a

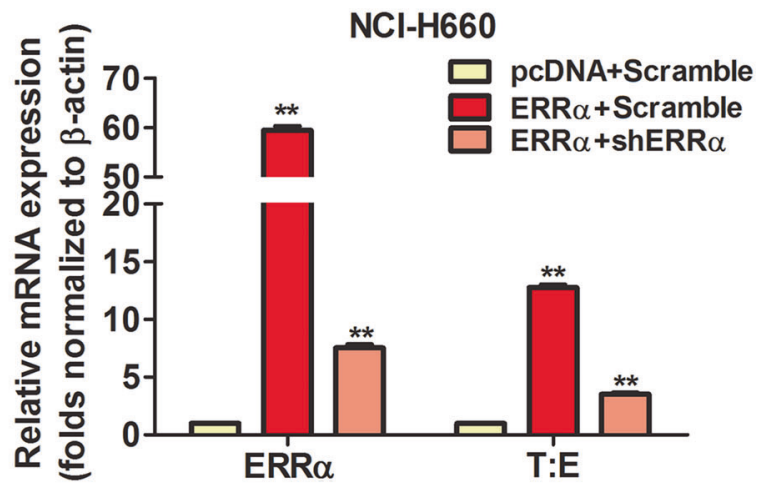

b

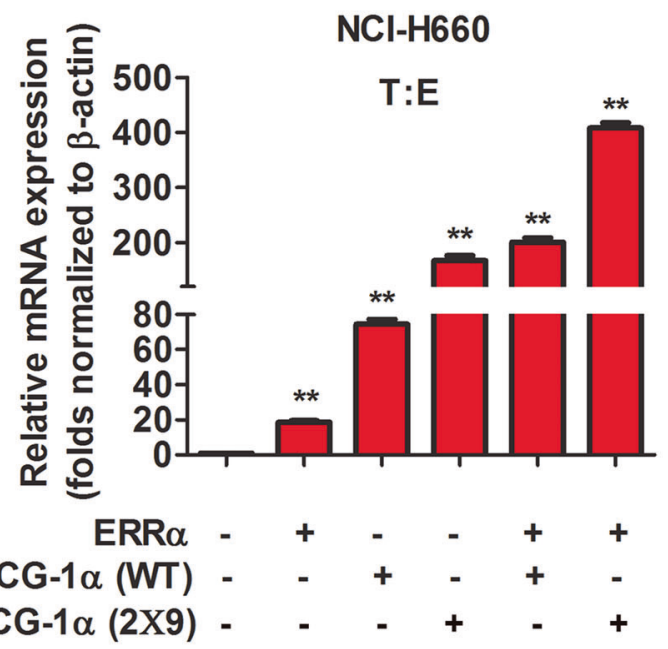

C

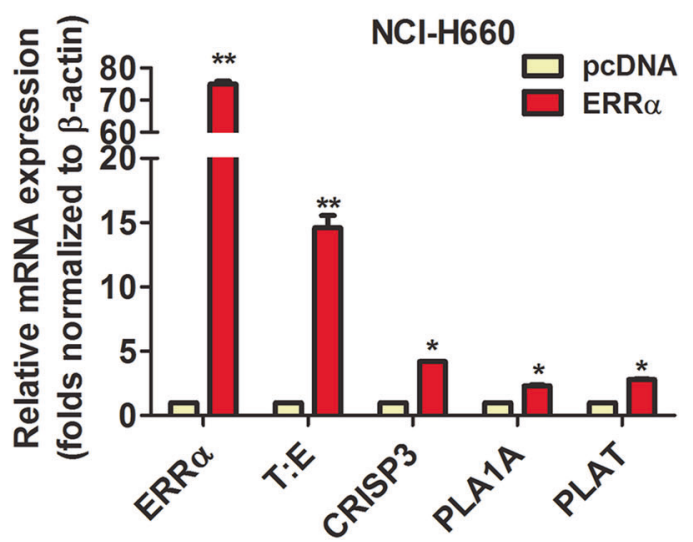

Fig. 4 ERR $\alpha$ overexpression increases T:E fusion or ERG expression and enhances ERG-mediated signaling in AR-negative NCI-H660 cells. a mRNA levels of T:E fusion could be significantly increased by transient ERR $\alpha$ transfection but attenuated by cotransfection with ERR $\alpha$ and shERR $\alpha$. b ERR $\alpha$-induced increase of T:E fusion mRNA levels could be further enhanced by co-transfection with coregulator PGC- $1 \alpha$ or its ERR $\alpha$-specific mutant PGC- $1 \alpha(2 \times 9)$. $\mathbf{c}$ mRNA levels of ERG-responsive targets were significantly elevated by ERR $\alpha$ transfection. ${ }^{*} P<0.05 ;{ }^{* *} P<0.01$ versus empty vector pcDNA3.1

examined whether ERR $\gamma$ knockdown could affect the T:E fusion expression in prostate cancer cells. Results showed that transient ERR $\gamma$ knockdown induced no change in T:E fusion expression in $\mathrm{VCaP}$ cells (Supplementary Fig. S3c). No detectable change in mRNA levels of ERG-responsive targets was shown in T:E-negative LNCaP cells and also no change in AR levels in VCaP cells upon XCT790 treatment or ERR $\alpha$ knockdown (Supplementary Fig. S4). Since T:E fusion gene possesses the same promoter of TMPRSS2 gene, we also determined that suppression of ERR $\alpha$ activity by XCT790 could decrease the endogenous TMPRSS2 transcripts in both $\mathrm{T}$ :E-positive $\mathrm{VCaP}$ and $\mathrm{T}$ :E-negative LNCaP cells (Supplementary Fig. S2d, e). In order to provide an insight into whether AR signaling would be involved in the ERR $\alpha$-mediated regulation of T:E expression, we next examined the effects of inhibition of AR activity (by flutamide or enzalutamide) or AR knockdown (siAR) and XCT790 treatment in T:E suppression in VCaP cells. Our results showed that XCT790-induced T:E suppression at similar or lower magnitude as AR antagonist or siAR in VCaP cells, with or without stimulation with AR agonist (R1881 or DHT), and with further T:E suppression by combined XCT790-AR antagonist/siAR treatments (Supplementary Fig. S5). These results suggest that suppression of $\mathrm{T}: \mathrm{E}$ expression by ERR $\alpha$ inhibition in ARpositive prostate cancer cells is independent of AR or the involvement of AR is minimal in this suppression. To further elucidate the significance of ERR $\alpha$ on the regulation of $\mathrm{T}: \mathrm{E}$ fusion in AR-negative prostate cancer cells, we then examined the effect of ectopic overexpression of ERR $\alpha$ in NCI-H660 cells. Results showed that transient transfection of ERR $\alpha$ could significantly increase the mRNA levels of T: E fusion transcripts, with further enhancement by cotransfection with either its wild-type coregulator PGC- $1 \alpha$ or ERR $\alpha$-specific mutant PGC- $1 \alpha(2 \times 9)$ but attenuated by ERR $\alpha$ knockdown, in NCI-H660 cells (Fig. 4a, b). Overexpression of ERR $\alpha$ could elevate the mRNA levels of multiple ERG-responsive targets (Fig. 4c). Together, these results suggest that $\mathrm{T}: \mathrm{E}$ fusion or ERG expression and its downstream ERG-mediated signaling can be positively regulated by ERR $\alpha$ in prostate cancer cells independent of their AR expression status.

\section{ERRa can directly transactivate T:E fusion gene in AR-positive and AR-negative prostate cancer cells}

We next sought to determine whether up-regulation of T:E fusion gene or T:E-expressed ERG as induced by ERR $\alpha$ in prostate cancer cells could be mediated by direct transactivation of its gene or indirect regulation via other ERR $\alpha$ regulated downstream signaling pathways. Sequence analysis predicted a total of six potential ERR $\alpha$-binding sites in the promoter and enhancer region of $\mathrm{T}: \mathrm{E}$ fusion gene, including four putative ERR $\alpha$-binding element/ERRE-containing ( $\mathrm{P} 2-5$ sites distributing over the region -3 to $-8 \mathrm{~kb}$ upstream of TMPRSS2 transcription start site) and two 
a

$T: E$ fusion gene enhancer/promoter region
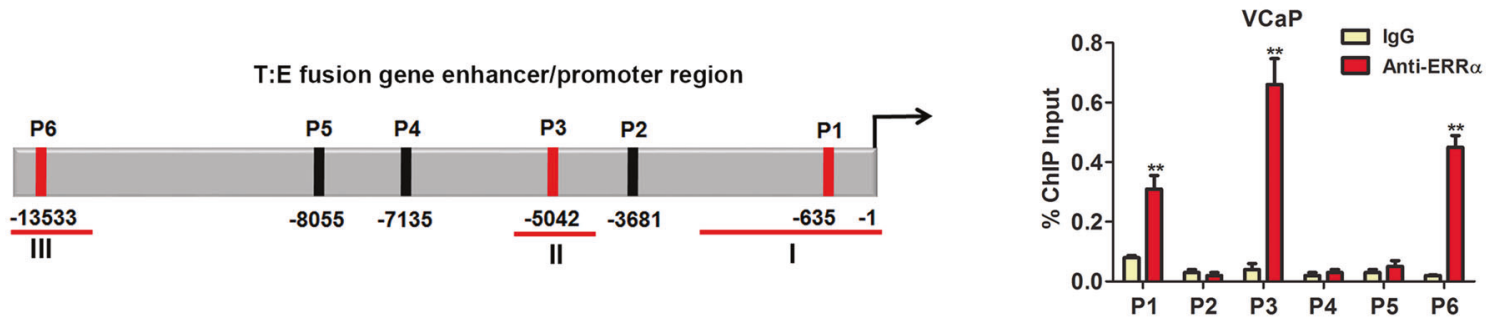

b

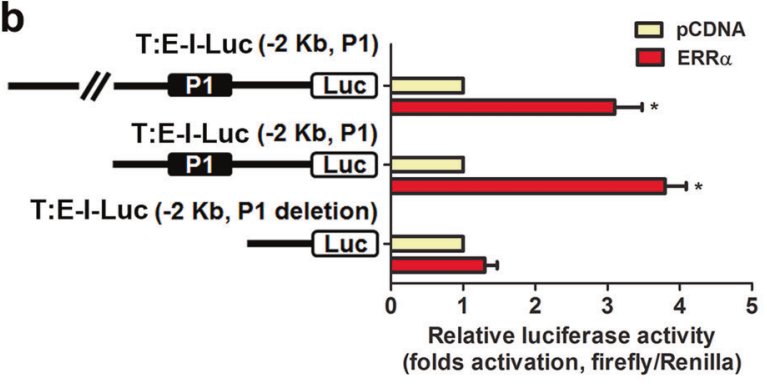

d

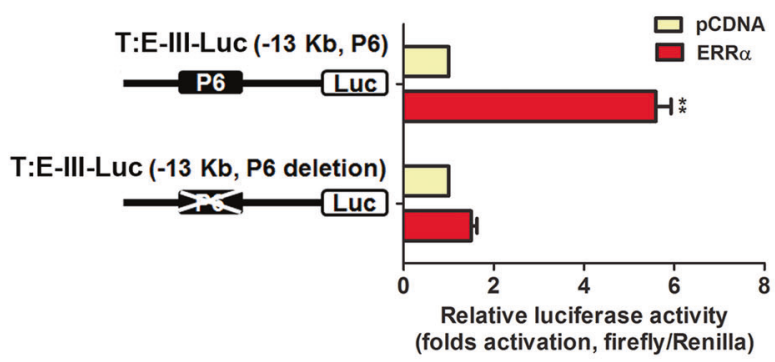

C
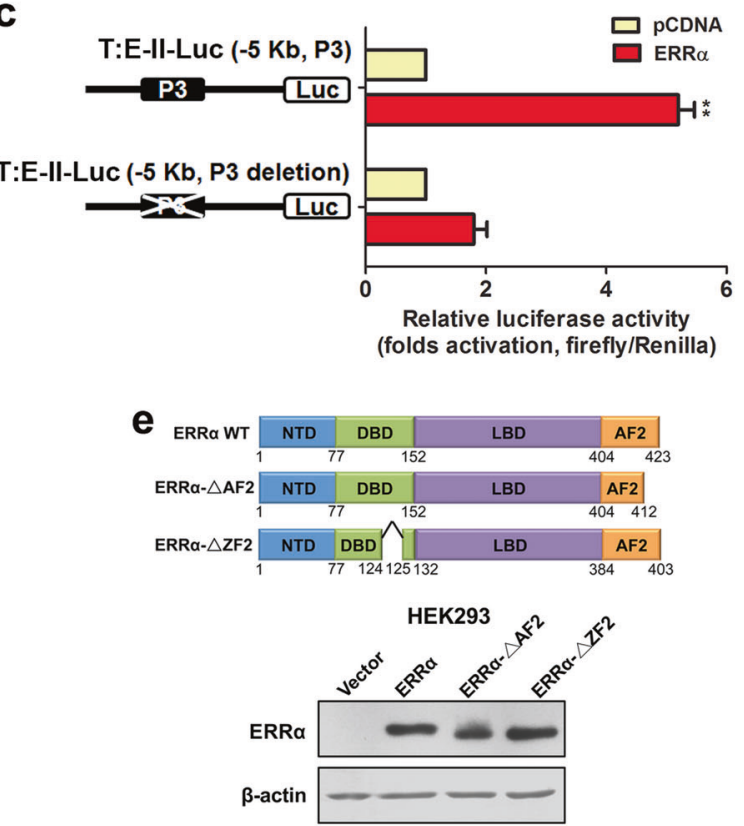

h

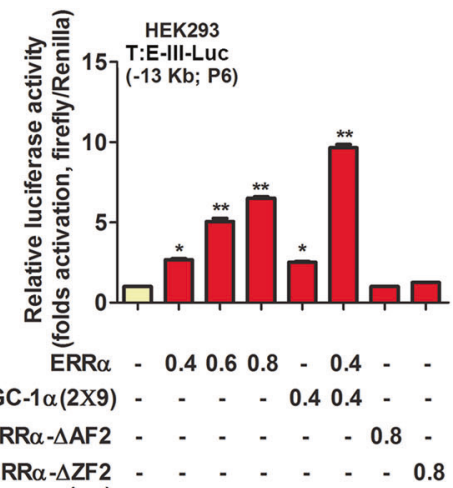

$(\mu \mathrm{g})$
Fig. 5 ERR $\alpha$ can directly transactivate the T:E fusion gene in ARpositive prostate cancer cells. a ChIP assay of T:E fusion gene performed in AR-positive VCaP cells. Left panel: schematic diagram shows the predicted ERR $\alpha$-binding sites (P1-P6) located in the promoter and enhancer regions of T:E fusion gene. Right panel: results validated that three sites, namely P1, P3, and P6, located respectively at $-640 \mathrm{bp},-5 \mathrm{~kb}$ and $-13.5 \mathrm{~kb}$ upstream of the T:E fusion gene transcription start site, were enriched of ERR $\alpha$. b-d Luciferase reporter assays of T:E fusion gene regulatory regions performed in ERR $\alpha$-transfected HEK293 cells. All three T:E-I/II/III-Luc reporter constructs, driven by different lengths of T:E promoter/enhancer fragments, could be significantly transactivated by ERR $\alpha$. Deletion of ERR $\alpha$ binding motifs in the T:E-Luc reporters abolished or significantly reduced the ERR $\alpha$-induced transactivation. e Upper panel: Schematic diagram shows the domain structures of the wildtype ERR $\alpha$ protein and its truncated mutants. Lower panel: Immunoblot detection of transfected ERR $\alpha$ and its truncated mutants in HEK293 cells. (f-h) Luciferase reporter assays of T:E-I/II/III-Luc constructs performed in HEK293 cells. All three reporter constructs could be dose-dependently transactivated by ERR $\alpha$, with further potentiation by co-transfection with PGC- $1 \alpha(2 \times 9)$, but not by ERR $\alpha$ $\Delta \mathrm{AF} 2$ and ERR $\alpha-\Delta \mathrm{ZF} 2$ truncated mutant constructs. ${ }^{*} P<0.05 ;{ }^{* *} P<$ 0.01 versus empty vector pcDNA3.1; two-tailed Student's $t$ test. All data are presented as mean \pm SEM obtained from three independent experiments 
androgen-responsive element/ARE-containing sites (P1 and P6 sites located at $-600 \mathrm{bp}$ and $-13 \mathrm{~kb}$ upstream of TMPRSS2 transcription start site). ChIP assays performed in AR-positive $\mathrm{VCaP}$ cells validated that among these potential binding sites, ERR $\alpha$ could directly bind to three sites, namely the ERRE-containing P3 site and two AREcontaining P1 and P6 sites (Fig. 5a). ChIP assay performed in another T:E-positive but AR-negative NCI-H660 cells showed that ERR $\alpha$ could directly bind to the P3 site (Supplementary Fig. S6a). Previous studies show that besides ERRE-binding motifs, ERR $\alpha$ can bind to the ARE sites present in the AR-target PSA promoter [32]; and also the designated P1 and P6 binding sites as identified at the TMPRSS2 gene promoter are characterized as the androgenregulated motifs [33]. Based on our ChIP results, we generated three luciferase reporter constructs (T:E-I/II/III-Luc), which contained the $\mathrm{T}$ :E promoter or enhancer regions with the ERRE/ARE-containing sites (P1, P3, or P6), for reporter gene analysis. Reporter assays performed in HEK293 cells showed that these $\mathrm{T}$ :E-Luc reporter constructs, driven by different T:E promoter/enhancer fragments, could be significantly transactivated by the transfected ERR $\alpha$ (Fig. $5 \mathrm{~b}-\mathrm{d})$, and their ERR $\alpha$-induced transactivation could be inhibited by XCT790 (Supplementary Fig. S6b-d). However, deletion of the ERRE/AREs in these reporters abolished their transactivation, suggesting these binding motifs present at the T:E promoter/enhancer were essential for the ERR $\alpha$-mediated transactivation. Further truncation analysis of the functional domains of $\mathrm{ERR} \alpha$ showed that the T:ELuc reporters could only be transactivated by the intact ERR $\alpha$ but not its AF2/DBD-truncated mutants, with further enhancement by cotransfection with ERR $\alpha$-specific coregulator PGC-1 $\alpha(2 \times 9)$, suggesting that an intact ERR $\alpha$ would be required for the transactivation of $\mathrm{T}: \mathrm{E}$ fusion gene (Fig. 5e-h). Additionally, transactivation of AREcontaining T:E-Luc-I/III-Luc reporter constructs could be further potentiated by cotransfection with AR (Supplementary Fig. S6e-g). To further address whether the ERR $\alpha$ binding to regulatory regions of $\mathrm{T}: \mathrm{E}$ fusion gene would be affected by AR signaling, we next performed ChIP assay in VCaP cells with AR inhibition. Results showed that binding of $E R R \alpha$ to the $T: E$ promoter-enhancer regions was not affected by AR knockdown or inhibition and conversely inhibition of ERR $\alpha$ by XCT790 did not affect AR binding to $\mathrm{T}: \mathrm{E}$ regulatory regions (Supplementary Fig. S7a-c). These results suggest that the binding of ERR $\alpha$ and AR to the $\mathrm{T}: \mathrm{E}$ fusion gene enhancer or promoter regions are independent of each other in prostate cancer cells. Finally, to elucidate whether the promoter-enhancer regions would interact mutually or form DNA looping in the ERR $\alpha$ mediated transactivation of $\mathrm{T}: \mathrm{E}$ fusion gene, we performed the ChIP-3C assay in VCaP cells. Results showed that a PCR product could be amplified in chromatin religated between promoter and enhancer (P6) regions of T:E fusion gene and the PCR signal was significantly suppressed in VCaP cells upon ERR $\alpha$ inhibition (XCT790) but not AR inhibition (siAR or enzalutamide) (Supplementary Fig. S7d), suggesting that ERR $\alpha$ could induce a promoterenhancer DNA looping in transactivation of $\mathrm{T}: \mathrm{E}$ fusion gene in prostate cancer cells. Together, these results suggest that $\mathrm{ERR} \alpha$ can directly transactivate the $\mathrm{T}: \mathrm{E}$ fusion gene via its direct binding to multiple binding motifs in the TMPRSS2 promoter.

\section{Enhanced T:E fusion-mediated invasion and metastasis capacity in AR-negative prostatic cells is under ERRa regulation}

In order to elucidate the significance of ERR $\alpha$ in the regulation of $\mathrm{T}: \mathrm{E}$ fusion gene and its contribution to the malignant growth capacity of prostate cancer cells without the AR influence, we generated stable T:E fusiontransduced infectants in three AR-negative prostatic cell lines (PC-3, BPH-1, and NCI-H660) using a T:E fusion expression plasmid pLenti-P-T:E, in which the ERG expression was driven specifically by a fragment of ERR $\alpha$ regulating $\mathrm{T}: \mathrm{E}$ promoter containing the $\mathrm{P} 1 \mathrm{ERR} \alpha$-binding site (Fig. 6a). Immunoblot analysis validated that only the PC-3-T:E and BPH-1-T:E infectants generated by the T:E promoter-containing pLenti-P-T:E plasmid positively expressed ERG, but not the promoter-less pLenti-T:E plasmid (Fig. 6b, c; Supplementary Fig. S8). Results also validated that the protein expression levels of ERG in these T:E fusion infectants were not affected upon DHT treatment, further demonstrating that the ectopic ERG expression in these $\mathrm{T}: \mathrm{E}$ fusion infectants was solely regulated by ERR $\alpha$ but not AR. Furthermore, shRNA-mediated knockdown of endogenous $E R R \alpha$ resulted in a significant reduction of both $\mathrm{mRNA}$ and protein expression levels of ERG in these T:E infectants (Fig. 6d, e). Together, these results showed that the ectopic expression of ERG in these $\mathrm{T}: \mathrm{E}$ infectants was under the regulation of $\mathrm{ERR} \alpha$ but unresponsive to androgen. Since T:E fusion is associated with prostate cancer invasion [9], we next examined the effects of ERR $\alpha$-regulated ectopic T:E fusion on the invasion capacity of prostatic cells. Transwell invasion assay showed that PC-3-T:E, BPH-1-T:E, and NCI-H600-T:E infectants exhibited higher invasion capacity as compared to their control vector-infectants and knockdown of ERR $\alpha$ resulted in reduced invasion capacity of T:E infectants (Fig. 6f, g; Supplementary Fig. S9). Our findings are consistent with a previous study that ectopic ERG overexpression can increase invasion capacity in benign immortalized (RWPE) and primary cultured (PrEC) prostatic epithelial cells [34]. In addition, in vivo tumorigenicity and metastasis studies on a highly metastatic AR-negative PC-3 subline PC-3M 
a

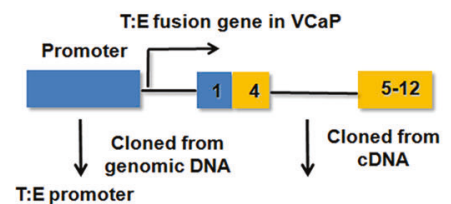

ERRE

ERG ORF

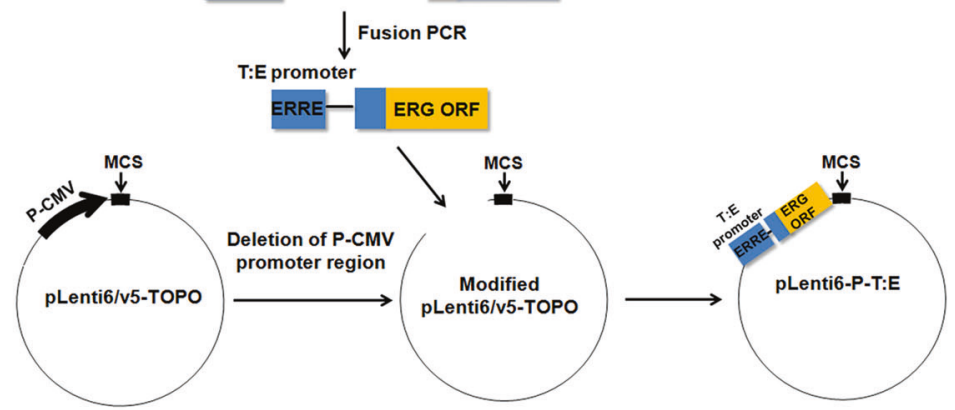

b

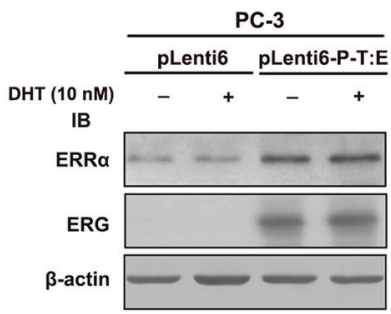

d

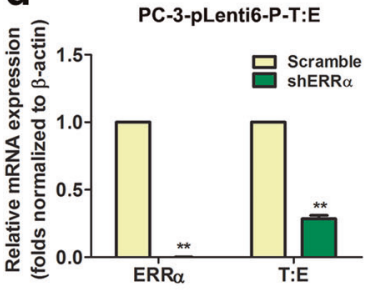

f
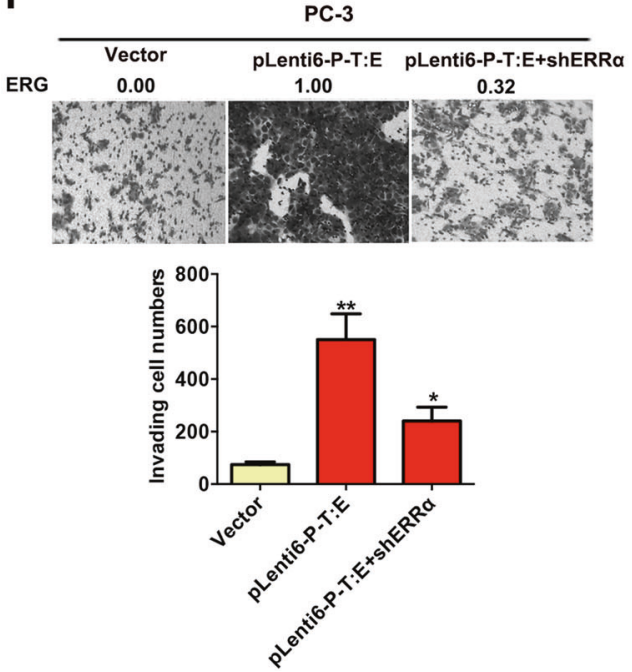

showed that ectopic T:E fusion expression in PC-3M cells could significantly promote their in vivo tumor growth and lymph node metastasis capacities in host SCID mice, as
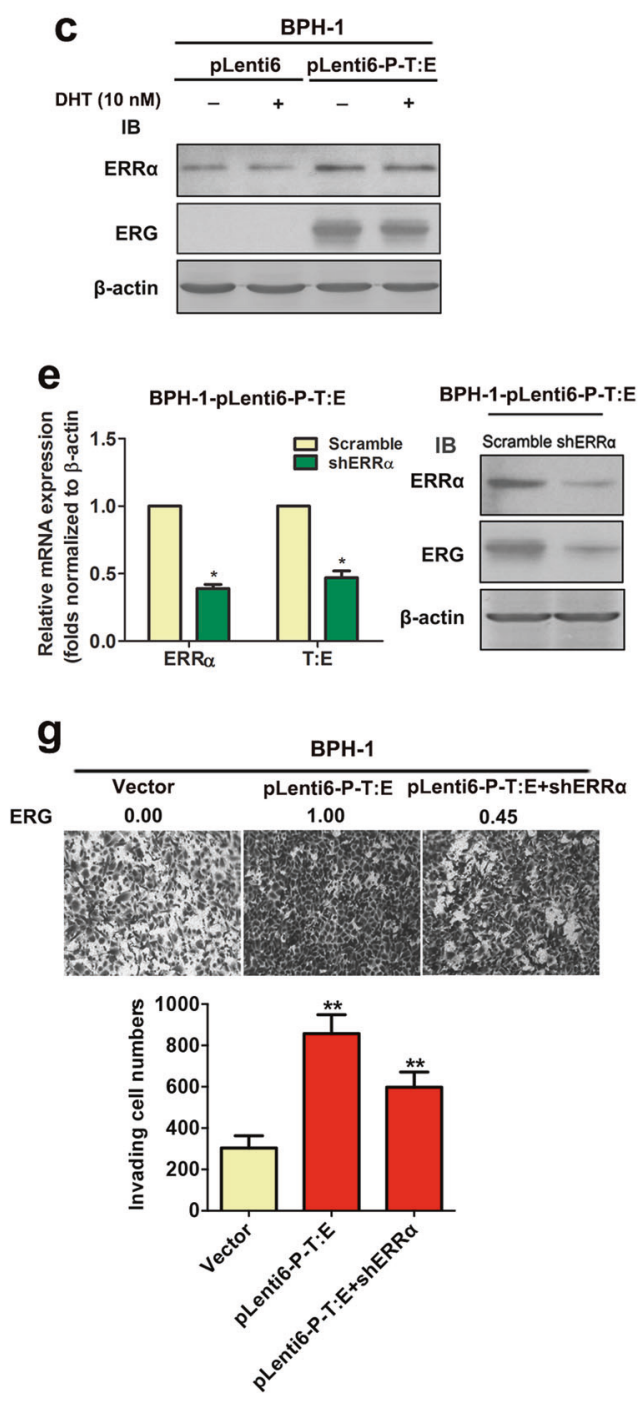

compared to their control counterpart PC-3M-vector/Luc ${ }^{+}$ infectants (Supplementary Fig. S10). Knockdown of endogenous ERR $\alpha$ in PC-3M-T:E-shERR $\alpha / \mathrm{Luc}^{+}$infectants 
Fig. 6 Enhanced invasion capacity mediated by ectopic T:E fusion or ERG in AR-negative prostatic cells is under ERR $\alpha$ regulation. a Schematic diagram shows the construction of the lentiviral plasmid expressing the T:E fusion or ERG under the regulation of ERR $\alpha$. An approximate $2-\mathrm{kb}$ fragment of the innate $\mathrm{T}: \mathrm{E}$ fusion gene promoter including the P1 ERR $\alpha$-binding element and the full-length open reading frame $(\mathrm{ORF})$ of the $\mathrm{T}: \mathrm{E}$ fusion gene was cloned from the genomic DNA and cDNA respectively from the T:E fusion-positive $\mathrm{VCaP}$ cells. The two DNA fragments were PCR-ligated and inserted into the modified CMV promoter-deleted lentiviral expression vector pLenti6-V5-TOPO as pLenti6-P-T:E. Under the regulation of its innate promoter containing the P1 ERR $\alpha$-binding element, the generated pLenti6-P-T:E expresses the T:E fusion or ERG. $\mathbf{b}$ and $\mathbf{c}$ Immunoblot analyses of ERR $\alpha$ and ERG in T:E fusion stable infectants of PC-3 and BPH-1 cells. Results validated that ERG was expressed in both PC-3$\mathrm{T}: \mathrm{E}$ and BPH-1-T:E infectants, with no alteration upon dihydrotestosterone (DHT) treatment. $\mathbf{d}$ and e RT-qPCR and immunoblot analyses of ERR $\alpha$ and ERG in ERR $\alpha$-knockdown T:E infectants. Results showed that both mRNA and protein levels of ERG were significantly reduced in both PC-3-T:E and BPH-1-T:E infectants upon shRNA-induced knockdown of ERR $\alpha$. $\mathbf{f}$ and $\mathbf{g}$ Transwell invasion assay on PC-3-T:E and BPH-1-T:E infectants. Upper panels: representative images show the crystal violet-stained invading $\mathrm{T}: \mathrm{E}$ infectants, magnification 100×. Analysis showed that both PC-3-T:E and BPH-1-T:E infectants exhibited significant higher invasion capacity than their control counterpart vector-infectants. The invasion capacities of both T:E infectants were significantly suppressed upon shRNA-induced knockdown of ERR $\alpha$. Figures above the images indicate the relative expression levels of ERG in respective clones. ${ }^{*} P<0.05 ;{ }^{* *} P<0.01$ versus empty vector-infectants, two-tailed Student's $t$ test. All data are presented as mean \pm SEM obtained from three independent experiments

could significantly suppress the T:E-induced in vivo malignant growth capacities. Together, our findings indicate that ectopic T:E fusion expression under the ERR $\alpha$ regulation can promote both the in vitro invasion and in vivo metastasis capacities of AR-negative prostatic cells and such T:E-mediated malignant growth potentials can be significantly attenuated by knockdown of endogenous ERR $\alpha$.

\section{ERG can directly transactivate ERRa gene in prostatic cells}

Intriguingly, we observed that $\mathrm{T}: \mathrm{E}$ infectants of ARnegative prostatic cells expressed significant higher mRNA and protein expressions of ERR $\alpha$ as compared to their counterpart controls vector-infectants (Fig. 7a, b; Supplementary Fig. S9a). Furthermore, we also detected that shRNA knockdown of endogenous T:E fusion gene expression could decrease both mRNA and protein levels of $\mathrm{ERR} \alpha$ in T:E fusion-positive $\mathrm{VCaP}$ and NCI-H660 cells (Fig. 7c, Supplementary Fig. S9b). Based on these findings, we hypothesize that the ERG expressed by T:E fusion gene could target to the ERR $\alpha$ gene in prostate cancer cells. Sequence analysis of the ERR $\alpha$ gene promoter predicted four potential ERG-binding sites (ERGREs, E1-E4), distributing over the 10-kb upstream of ERR $\alpha$ (ESRRA) promoter or regulatory region. To verify this, we performed the ChIP assays in the T:E fusion-positive $\mathrm{VCaP}$ cells. Results showed that among the four potential ERG-binding sites, the E1 site located at -635 bp upstream of the ERR $\alpha$ transcription start site was enriched of ERG (Fig. 7d). Furthermore, luciferase reporter assays performed in HEK293 cells, using a reporter construct ERR $\alpha$-Luc driven by a 645 -bp fragment of ERR $\alpha$ gene promoter $(-645$ to -1 bp) and a derived mutant construct with E1 deletion, showed that the ectopic transfected T:E fusion could induce the transactivation of ERR $\alpha$-Luc reporter but not its E1deleted mutant reporter (Fig. 7e). Reporter assay also showed that the ERR $\alpha$-Luc (E1) reporter construct could be significantly and dose-dependently transactivated by the transfected T:E (Fig. 7f). These results manifested that the T:E fusion-expressed ERG could directly transactivate the ERR $\alpha$ gene in prostate cancer cells. Together with the direct ERR $\alpha$ targeting to the T:E fusion gene, our findings indicate that ERR $\alpha$ and ERG can form a reciprocal regulatory loop in their transactivations in prostate cancer cells and both cooperate with each other to advance the prostate cancer progression (Fig. $7 \mathrm{~g}$ ).

\section{Discussion}

Although the expression of T:E fusion is closely associated with more aggressive tumors and higher rate of recurrence [7, 10, 11,35-37], its clinical value as a reliable diagnostic and prognostic marker of prostate cancer still remains controversial [38-42]. Our present association results showed that overexpressions of both ERR $\alpha$ and ERG were closely associated with higher Gleason scores and metastasis in prostate cancer patients. It is apparent that increased expressions of both ERR $\alpha$ and ERG would contribute to a more aggressive phenotype of prostate cancer. Our data suggest that together with the demonstrated oncogenic roles performed by ERR $\alpha$ and ERG, combined evaluation of coexpressions of ERR $\alpha$ and ERG may provide a better prognosis for prostate cancer or predictor of sensitivity to hormone therapy.

Since the prostate cancer-prevalent T:E fusion gene is formed by the fusion with the androgen-responsive regulatory region of the AR-targeted TMPRSS2 gene, it is generally viewed that $\mathrm{T}: \mathrm{E}$ fusion is primarily regulated by $\mathrm{AR}$ and its aberrant expression in androgen-dependent prostate cancer is mainly attributed to the activated AR signaling, and AR targeting by androgen ablation or hormone therapy could help to suppress its aberrant overexpression in prostate cancer. However, its regulation wholly by AR in CRPC still remains elusive. In a previous study of patient-derived T:E-positive prostate cancer 
Fig. 7 ERG can directly transactivate ERR $\alpha(E S R R A)$ gene in prostatic cells. a and b RT-qPCR and immunoblot analyses of ERG and ERR $\alpha$ expressions in T:E fusion infectants. Results showed that both mRNA and protein expressions of ERR $\alpha$ were significantly increased in both PC-3-T:E and BPH-1-T:E infectants. c RT-qPCR and immunoblot analyses of ERG and $\mathrm{ERR} \alpha$ expressions in $\mathrm{VCaP}$ cells upon shRNA knockdown of T:E fusion. Results showed that both mRNA and protein expressions of ERR $\alpha$ were significantly reduced in $\mathrm{VCaP}$ cells upon shRNA knockdown of T:E. d ChIP assay. Left panel: schematic diagram shows the locations of potential ERGbinding sites (E1-E4), as predicted by promoter sequence analysis, at the promoter or regulatory region of ERR $\alpha$ gene. Right panel: ChIP assay performed in $\mathrm{VCaP}$ cells validated that only the E1 site but not others showed significant enrichment of ERG. e and $\mathbf{f}$ Luciferase reporter assays of ERR $\alpha$ gene promoter transactivation performed in $\mathrm{T}$ : E-transfected HEK293 cells. Results showed that the ERR $\alpha$ Luc reporter, driven by a proximal ERR $\alpha$ gene promoter fragment containing the E1 element, could be significantly and dose-dependently transactivated by the transfected $\mathrm{T}$ :E. Deletion of the E1 element in the reporter abolished the $\mathrm{T}$ : E-induced transactivation of the reporter. ${ }^{*} P<0.05 ;{ }^{* *} P<0.01$, two-tailed Student's $t$ test. All data are presented as mean \pm SEM obtained from three independent experiments. g Schematic diagram shows the hypothesis on the reciprocal transactivations between ERR $\alpha$ and ERG expressed by the T:E fusion gene and their synergic contribution toward the prostate cancer progression a
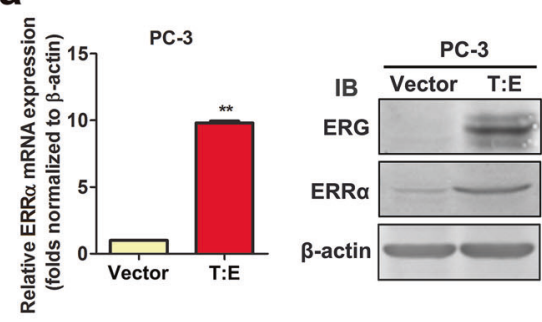

C

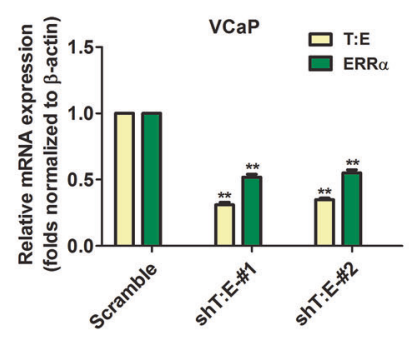

b

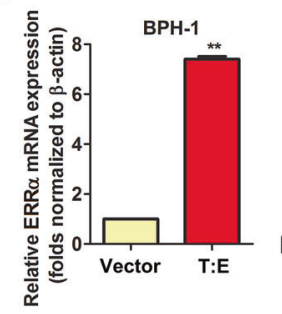

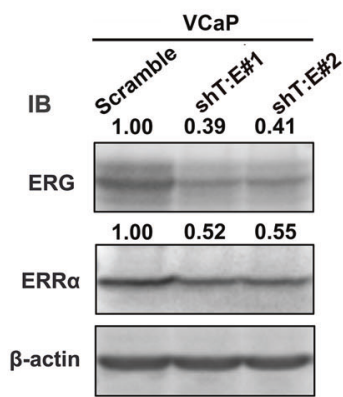

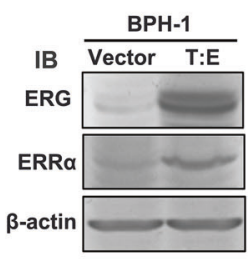

d
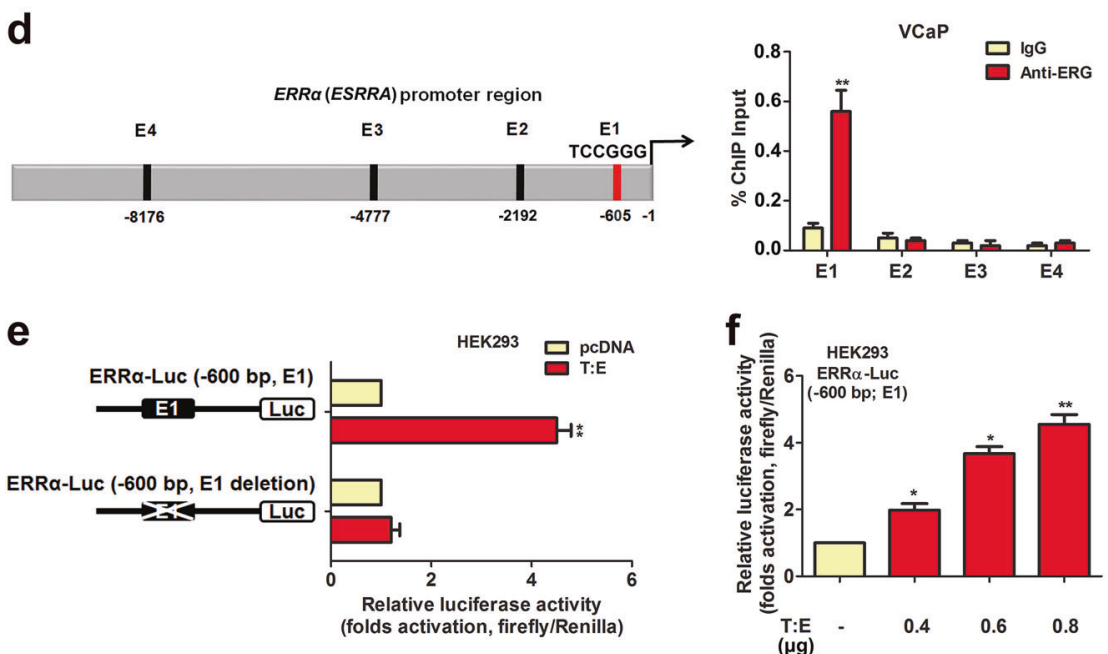

g

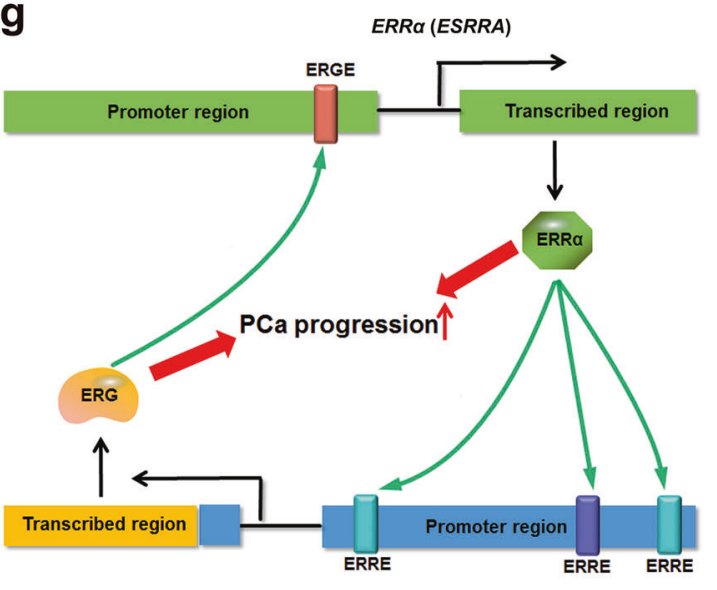

TMPRSS2:ERG xenografts, Hermans et al. show that AR-positive and androgen-sensitive xenografts express high levels of T:E fusion transcripts, whereas some AR-negative and androgen-insensitive xenografts still express a basal level of ERG or no expression, and thus conclude that T:E fusion expression is functionally correlated with AR expression 
and its AR-dependent regulation may be bypassed in latestage AR-negative prostate cancer [16]. In another study, Cai et al. [43] also show that ERG is expressed at comparable levels in $\mathrm{T}$ :E-positive androgen-dependent primary prostate cancer and androgen-independent CRPC; and in T: E-positive VCaP xenografts, its levels shows initial downregulation in castrated mice but returns to precastration levels in relapse tumors. However, this proposed mechanism of action by AR activation cannot explain the expression of $\mathrm{T}: \mathrm{E}$ fusion gene in advanced metastatic hormone therapy-resistant prostate cancer and AR-negative and androgen-independent prostate cancer cells [12, 16, 17, 21]. Moreover, in another study in clinical T:E-positive prostate cancer tissues, it is reported that prostatic $\mathrm{T}: \mathrm{E}$ expression still remains persistent in some patients pre-treated with androgen ablation before surgery [44]. These contrasting results suggest a notion that $\mathrm{T}: \mathrm{E}$ fusion expression may become androgen-independent or bypass in advanced prostate cancer and be regulated by other transcription factors or nuclear receptors. Indeed, our study of VCaPCRPC xenograft model revealed that AR (full-length ARFL and its spliced variant AR-V7), ERR $\alpha$ and ERG showed increased expressions in castration-relapse VCaP-CRPC tumors, with further increase of $\mathrm{AR}$ and $\mathrm{ERR} \alpha$ upon enzalutamide treatment, but the AR signaling (shown by PSA level) did not show significant reactivation correspondingly (Supplementary Fig. S11). These results suggest that besides AR, ERR $\alpha$ may become a key regulator of T:E fusion gene in CRPC.

Here, we showed for the first time that $\operatorname{ERR} \alpha$ can transactivate the $\mathrm{T}: \mathrm{E}$ fusion gene via its direct binding to TMPRSS2 promoter/enhancer in both AR-positive and -negative prostate cancer cells, with further potentiation by its coregulator PGC-1 $\alpha$. This direct regulation of $\mathrm{T}: \mathrm{E}$ fusion by $\mathrm{ERR} \alpha$ is independent of $\mathrm{AR}$ expression status in prostate cancer cells as evidenced by its transactivation by $\mathrm{ERR} \alpha$ in AR-negative NCI-H660 cells. Since ERR $\alpha$ can cross-talk to AR signaling by its direct transactivation of common AREcontaining AR targets [32], it could be likely that the transactivation of $\mathrm{T}: \mathrm{E}$ fusion gene by $\mathrm{ERR} \alpha$ could be indirectly mediated through its interference on AR signaling in prostate cancer cells. Our data showed that suppression of $\mathrm{ERR} \alpha$ by either XCT790 or shRNA-ERR $\alpha$ induced no change in AR mRNA levels in VCaP cells (ER $\alpha$-negative and low ER $\beta$ ) (Supplementary Fig. S4c, d), suggesting that the T:E suppression involves no perturbation of AR expression. Moreover, we also showed that ERR $\alpha$ inhibition by XCT790 could induce more or similar suppression of $\mathrm{T}$ : $\mathrm{E}$ expression as compared to $\mathrm{AR}$ inhibition or its knockdown in AR-positive VCaP cells, with or without stimulation with AR agonist (Supplementary Fig. S5). Together, our results suggest that the ERR $\alpha$-mediated direct transactivation of $\mathrm{T}: \mathrm{E}$ fusion gene would involve minimal or no cross-talk with AR in prostate cancer cells. Our present findings not only suggest a new role for ERR $\alpha$ in the regulation of $\mathrm{T}: \mathrm{E}$ fusion expression in an $\mathrm{AR}$-independent manner but also provide an insight on the persistent $\mathrm{T}$ : $\mathrm{E}$ expression in CRPC and androgen-independent prostate cancer [43, 44] in which AR-signaling is perturbed and $\mathrm{ERR} \alpha$ shows an up-regulation pattern.

In a previous cDNA microarray expression profile study on two cohorts of prostate cancer patients, a fusion genespecific signature is identified to be associated with ER signaling in T:E-positive prostate cancer tissues [22]. The authors also show by in vitro functional studies that the T:E fusion expression can be modulated by some ER ligands in T:E-positive NCI-H660 and VCaP cells, and hypothesize that the T:E expression can be down-regulated by an ER $\beta$ dependent mechanism in prostate cancer cells. However, the significance of ER signaling in prostate cancer progression and the genuine value of $E R \alpha / \beta$ as prognostic markers still remains controversial. On the other hand, our present data showed that ectopic expression of either $\operatorname{ERR} \alpha$ or its coactivator PGC-1 $\alpha$ could induce significant increased expression of T:E but no change in $\mathrm{ER} \alpha$ and $\mathrm{ER} \beta$ in NCIH660 cells (Supplementary Fig. S12), suggesting that the regulation of $\mathrm{T}: \mathrm{E}$ fusion gene by $\mathrm{ERR} \alpha$ was independent of ERs in prostate cancer cells, at least in AR-negative cells.

Intriguingly, our studies showed that ERR $\alpha$ and ERG could positively regulate each other at their gene promoters and appear to constitute a reciprocal loop in prostate cancer cells. This ERR $\alpha$-ERG positive feedback loop between ERR $\alpha$ and ERG may help to explain their concomitant increased expression patterns in advanced prostate cancer. However, it still remains to further determine how this functional cooperation between ERR $\alpha$ and ERG could help to augment synergistically the signalings mediated by these transcriptional regulators respectively and also how the ERR $\alpha$-ERG loop plays in the promotion and progression of prostate cancer, particularly therapy-resistance and metastasis.

Since T:E fusion gene is initially characterized as an androgen-regulated gene, hormone therapy against androgen signaling is considered as a therapeutic strategy for targeting the $\mathrm{T}$ :E-positive prostate cancer. However, expression study shows that $\mathrm{T}: \mathrm{E}$ expression still remains persistent in clinical CRPC, CRPC xenograft tumors, and neuroendocrine prostate cancer [43]. Clinical association studies show no prediction on association between $\mathrm{T}$ : $\mathrm{E}$ fusion status and patient responsiveness to androgendeprivation and antiandrogen therapy [45, 46]. Moreover, $\mathrm{T}: \mathrm{E}$ expression status in circulating tumor cells isolated from metastatic CRPC patients shows no predictive response to androgen biosynthesis inhibitor abiraterone acetate [47]. All these studies manifest that hormone therapy against the androgen signaling is not enough to 
suppress or eradicate the T:E expression in CRPC. On the other hand, our present study suggests that targeting ERR $\alpha$, which directly upstream regulates the promoter of $\mathrm{T}: \mathrm{E}$ fusion, could be an attractive therapeutic approach to manage the T:E-positive prostate cancer.

In all, our present study suggests that the concomitant increased expressions of both ERR $\alpha$ and ERG, both are under a reciprocal transactivation feedback regulation between the two transcription factors, would perform a synergistic role in the advanced progression of prostate cancer (Fig. 7g). Our results also implicate that targeting ERR $\alpha$ could be a potential therapeutic strategy to suppress the T:E fusion gene expression in prostate cancer.

\section{Materials and methods}

\section{Determination of clinical profiles of $\mathrm{T}: \mathrm{E}$ fusion and ERRa in prostate cancer}

The frequencies of $\mathrm{T}: \mathrm{E}$ fusion and $\mathrm{ERR} \alpha$ alterations in prostate cancer patients were analyzed using datasets from the Cancer Genome Atlas-Cancer Genomics and assessed by the cBioPortal for Cancer Genomics, which contain clinical genomic details of approximate 499 patients (TCGA, Provisional, TCGA, Cell 2015) [48]. The mutated TMPRSS2 contain ERG insert was defined ERG(+) in this study $[49,50]$.

\section{Cell lines and cell culture}

Four human prostate cancer cell lines (LNCaP, VCaP, NCIH660, and PC-3) and one immortalized prostatic epithelial cell line (BPH-1) were used in this study. 293FT and HEK293, and viral packaging cells PA317 were used in transfection and retroviral packaging, respectively. The culture media and conditions were followed as described previously $[25,51]$.

\section{Plasmid construction}

(a) Expression plasmids: an approximate 2000-bp fragment of TMPRSS2 gene promoter containing an ERR $\alpha$-binding element (ERRE, P6) was fused with the full-length codingdomain sequence of $E R G$ by PCR-fusion method as the T:E fusion and cloned into a CMV promoter-deleted pLentiV6 vector as pLenti-P-T:E for lentiviral transduction. pLenti-T: E without TMPRSS2 gene promoter was also generated by insertion of $E R G$ cDNA only into CMV-minus pLentiV6 vector. Expression plasmids of ERR $\alpha$ (pcDNA3-ERR $\alpha /$ ERR $\alpha-\Delta Z$ ZF2/ERR $\alpha-A F 2)$ and PGC- $1 \alpha$ (pcDNA3-PGC-1 $\alpha /$ PGC- $1 \alpha 2 \times 9)$ were constructed as described previously
[27]. (b) shRNA plasmids: pLKO-shT:E\#1/2 plasmids were cloned by inserting the synthetic oligonucleotide primers against T:E fusion into lentiviral vector pLKO.1; previously validated pLKO-shERR $\alpha$ plasmids were used for RNA interference [27]. (c) Reporter plasmids: human T:E gene promoter of lengths varying from $-13 \mathrm{~kb}$ to $-300 \mathrm{bp}$ and ERR $\alpha$ (ESRRA) gene promoter ( -987 to $-1 \mathrm{bp}$ ) were PCRamplified from genomic DNA of $\mathrm{VCaP}$ cells and cloned into pGL3 basic vector as pGL3-T:E-Luc and pGL3-ERR $\alpha$ Luc for reporter gene assay.

\section{Lentiviral transduction}

Procedures on generation of stable T:E fusion- and empty vector-transduced cells, and shT:E- and shERR $\alpha$-transduced cells were followed as described previously [51, 52].

\section{Transwell invasion assay}

Assay was performed on T:E- and shERR $\alpha$-transduced prostatic cells following procedures as described previously $[53,54]$.

\section{RNA and protein analyses}

Procedures on PCR and immunoblotting are followed as described previously [52, 55], and sequences of primer pairs for different target genes are listed in Supplementary Table S1. Primary antibodies used include ERG (abcam), ERR $\alpha$ (Epitomics), and $\beta$-actin (Santa Cruz).

\section{Molecular biology analyses}

(a) Chromatin immunoprecipitation assay (ChIP). ChIP assays of endogenous T:E fusion gene and ERR $\alpha$ gene promoter were performed in $\mathrm{VCaP}$ cells following procedures as described previously [56]. Specific primer pairs for different target gene promoters are listed in Table S1. (b) ChIP-combined chromosome conformation capture assay (ChIP-3C). EcoRI was selected for enzyme digestion of chromatin after analysis of digestion map of the $-14 \mathrm{~kb}$ enhancer/promoter region of T:E fusion gene. ChIP-3C assay of $\mathrm{T}: \mathrm{E}$ fusion gene was performed in $\mathrm{VCaP}$ cells following a procedure as described previously [57]. Briefly, cross-linked chromatin was extracted from $\mathrm{VCaP}$ cells, sonicated, digested with EcoRI (TaKaRa) overnight and immunoprecipitated with protein A-agarose beads coupled with ERR $\alpha$-antibody. The beads were precipitated, resuspended in ligation buffer and ligated with T4 DNA ligase (TaKaRa) overnight. The religated protein-DNA complexes bounded to beads were eluted, purified for DNA and analysis by PCR. (b) Luciferase reporter assay. Dual-luciferase 
assay was performed in HEK293 cells. After 48-h posttransfection, cells were further treated with XCT790 or without for $24 \mathrm{~h}$, followed by measurement of luciferase activity as described previously [56].

\section{CRPC xenograft tumors}

CRPC xenograft model VCaP-CRPC was established based on the castration-refractory growth of tumors formed by subcutaneous implantation of VCaP cells in castrated SCID mice as described previously [58].

\section{In vivo tumorigenicity and metastasis assays}

In vivo tumorigenicity and metastasis assays were performed on empty vector-, T:E- or T:E-shERR $\alpha$-transduced and firefly luciferase-labeled PC-3M-Luc ${ }^{+}$cells following procedures as described previously [54].

\section{Statistical analysis}

Student's $t$ test was used to compare the means between two groups. One-way ANOVA test was used to compare multiple groups. $\quad P<0.05$ was considered statistically significant.

Acknowledgments This work was supported by grants from the General Research Funds (Project numbers 14100914 and 14107116), Research Grants Council of Hong Kong (to F.L.C.), University Natural Science Research Project of Anhui Province (KJ2016A732) (to Z. $X$.) and National Natural Science Foundation of China (81602240 to Z.X.; 81402370 to C.Z.).

Author contributions Z.X. and Y.W. performed all experiments and data analysis. Z.X., S.Y., and F.L.C. conceived experiments and research design. Z.G.X. performed bioinformatics analysis. C.Z., X. Z., Z.W. and D.W. performed plasmid construction and lentiviral transduction. S.Y. and F.L.C prepared and wrote the manuscript. Z.X., C.Z., and F.L.C. secured research funds.

\section{Compliance with ethical standards}

Conflict of interest The authors declare that they have no conflict of interest.

Open Access This article is licensed under a Creative Commons Attribution 4.0 International License, which permits use, sharing, adaptation, distribution and reproduction in any medium or format, as long as you give appropriate credit to the original author(s) and the source, provide a link to the Creative Commons license, and indicate if changes were made. The images or other third party material in this article are included in the article's Creative Commons license, unless indicated otherwise in a credit line to the material. If material is not included in the article's Creative Commons license and your intended use is not permitted by statutory regulation or exceeds the permitted use, you will need to obtain permission directly from the copyright holder. To view a copy of this license, visit http://creativecommons. org/licenses/by/4.0/.

\section{References}

1. Tomlins SA, Rhodes DR, Perner S, Dhanasekaran SM, Mehra R, Sun XW, et al. Recurrent fusion of TMPRSS2 and ETS transcription factor genes in prostate cancer. Science. 2005;310:644-8.

2. Feng FY, Brenner JC, Hussain M, Chinnaiyan AM. Molecular pathways: targeting ETS gene fusions in cancer. Clin Cancer Res. 2014;20:4442-8.

3. Clark JP, Cooper CS. ETS gene fusions in prostate cancer. Nat Rev Urol. 2009;6:429-39.

4. Rubin MA. ETS rearrangements in prostate cancer. Asian J Androl. 2012;14:393-9.

5. Perner S, Demichelis F, Beroukhim R, Schmidt FH, Mosquera $\mathrm{JM}$, Setlur S, et al. TMPRSS22:ERG fusion-associated deletions provide insight into the heterogeneity of prostate cancer. Cancer Res. 2006;66:8337-41.

6. Mosquera JM, Mehra R, Regan MM, Perner S, Genega EM, Bueti $\mathrm{G}$, et al. Prevalence of TMPRSS22-ERG fusion prostate cancer among men undergoing prostate biopsy in the United States. Clin Cancer Res. 2009;15:4706-11.

7. Mehra R, Tomlins SA, Shen R, Nadeem O, Wang L, Wei JT, et al. Comprehensive assessment of TMPRSS2 and ETS family gene aberrations in clinically localized prostate cancer. Mod Pathol. 2007;20:538-44.

8. Esgueva R, Perner S, LaFargue CJ, Scheble V, Stephan C, Lein $\mathrm{M}$, et al. Prevalence of TMPRSS2-ERG and SLC45A3-ERG gene fusions in a large prostatectomy cohort. Mod Pathol. 2010;23:539-46.

9. Perner S, Mosquera JM, Demichelis F, Hofer MD, Paris PL, Simko J, et al. TMPRSS2-ERG fusion prostate cancer: an early molecular event associated with invasion. Am J Surg Pathol. 2007;31:882-8.

10. Demichelis F, Fall K, Perner S, Andrén O, Schmidt F, Setlur SR, et al. TMPRSS2:ERG gene fusion associated with lethal prostate cancer in a watchful waiting cohort. Oncogene. 2007;26:4596-9.

11. Attard G, Clark J, Ambroisine L, Fisher G, Kovacs G, Flohr P, et al. Duplication of the fusion of TMPRSS2 to ERG sequences identifies fatal human prostate cancer. Oncogene. 2008;27:253-63.

12. Mehra R, Tomlins SA, Yu J, Cao X, Wang L, Menon A, et al. Characterization of TMPRSS2-ETS gene aberrations in androgenindependent metastatic prostate cancer. Cancer Res. 2008;68:3584-90.

13. Hägglöf C, Hammarsten P, Strömvall K, Egevad L, Josefsson A, Stattin $\mathrm{P}$, et al. TMPRSS2-ERG expression predicts prostate cancer survival and associates with stromal biomarkers. PLoS ONE. 2014;9:e86824.

14. Klezovitch O, Risk M, Coleman I, Lucas JM, Null M, True LD, et al. A causal role for ERG in neoplastic transformation of prostate epithelium. Proc Natl Acad Sci USA. 2008;105:2105-10.

15. Adamo P, Ladomery MR. The oncogene $E R G$ : a key factor in prostate cancer. Oncogene. 2016;35:403-14.

16. Hermans KG, van Marion $R$, van Dekken $H$, Jenster $G$, van Weerden WM, Trapman J. TMPRSS2:ERG fusion by translocation or interstitial deletion is highly relevant in androgendependent prostate cancer, but is bypassed in late-stage androgen receptor-negative prostate cancer. Cancer Res. 2006;66:10658-63.

17. Mertz KD, Setlur SR, Dhanasekaran SM, Demichelis F, Perner S, Tomlins S, et al. Molecular characterization of TMPRSS2-ERG gene fusion in the NCI-H660 prostate cancer cell line: a new perspective for an old model. Neoplasia. 2007;9:200-6.

18. Scheble VJ, Scharf G, Braun M, Ruiz C, Stürm S, Petersen K, et al. $E R G$ rearrangement in local recurrences compared to distant 
metastases of castration-resistant prostate cancer. Virchows Arch. 2012;461:157-62.

19. Beltran H, Rickman DS, Park K, Chae SS, Sboner A, MacDonald TY, et al. Molecular characterization of neuroendocrine prostate cancer and identification of new drug targets. Cancer Discov. 2011;1:487-95.

20. Schelling LA, Williamson SR, Zhang S, Yao JL, Wang M, Huang $\mathrm{J}$, et al. Frequent TMPRSS2-ERG rearrangement in prostatic small cell carcinoma detected by fluorescence in situ hybridization: the superiority of fluorescence in situ hybridization over ERG immunohistochemistry. Hum Pathol. 2013;44:2227-33.

21. Polson ES, Lewis JL, Celik H, Mann VM, Stower MJ, Simms MS, et al. Monoallelic expression of TMPRSS2/ERG in prostate cancer stem cells. Nat Commun. 2013;4:1623.

22. Setlur SR, Mertz KD, Hoshida Y, Demichelis F, Lupien M, Perner $\mathrm{S}$, et al. Estrogen-dependent signaling in a molecularly distinct subclass of aggressive prostate cancer. J Natl Cancer Inst. 2008;100:815-25.

23. Washington $\mathrm{MN}$, Weigel NL. $1 \alpha, 25$-Dihydroxyvitamin $\mathrm{D}_{3}$ inhibits growth of $\mathrm{VCaP}$ prostate cancer cells despite inducing the growth-promoting TMPRSS2:ERG gene fusion. Endocrinology. 2010;151:1409-17.

24. Giguère V. Transcriptional control of energy homeostasis by the estrogen-related receptors. Endocr Rev. 2008;29:677-96.

25. Cheung CP, Yu S, Wong KB, Chan LW, Lai FM, Wang X, et al. Expression and functional study of estrogen receptor-related receptors in human prostatic cells and tissues. J Clin Endocrinol Metab. 2005;90:1830-44.

26. Fujimura T, Takahashi S, Urano T, Kumagai J, Ogushi T, HorieInoue $\mathrm{K}$, et al. Increased expression of estrogen-related receptor $\alpha$ $(\mathrm{ERR} \alpha)$ is a negative prognostic predictor in human prostate cancer. Int J Cancer. 2007;120:2325-30.

27. Zou C, Yu S, Xu Z, Wu D, Ng CF, Yao X, et al. ERR $\alpha$ augments HIF-1 signalling by directly interacting with HIF- $1 \alpha$ in normoxic and hypoxic prostate cancer cells. J Pathol. 2014;233:61-73.

28. Fradet A, Bouchet M, Delliaux C, Gervais M, Kan C, Benetollo $\mathrm{C}$, et al. Estrogen-related receptor alpha in castration-resistant prostate cancer cells promotes tumor progression in bone. Oncotarget. 2016;7:77071-86.

29. Clark J, Merson S, Jhavar S, Flohr P, Edwards S, Foster CS, et al. Diversity of TMPRSS2-ERG fusion transcripts in the human prostate. Oncogene. 2007;26:2667-73.

30. Lanvin O, Bianco S, Kersual N, Chalbos D, Vanacker JM. Potentiation of ICI182,780 (fulvestrant)-induced estrogen receptor- $\alpha$ degradation by the estrogen receptor-related receptor- $\alpha$ inverse agonist XCT790. J Biol Chem. 2007;282:28328-34.

31. Wu D, Cheung A, Wang Y, Yu S, Chan FL. The emerging roles of orphan nuclear receptors in prostate cancer. Biochim Biophys Acta. 2016;1866:23-36.

32. Teyssier C, Bianco S, Lanvin O, Vanacker JM. The orphan receptor ERR $\alpha$ interferes with steroid signaling. Nucleic Acids Res. 2008;36:5350-61.

33. Wang Q, Li W, Liu XS, Carroll JS, Jänne OA, Keeton EK, et al. A hierarchical network of transcription factors governs androgen receptor-dependent prostate cancer growth. Mol Cell. 2007;27:380-92.

34. Tomlins SA, Laxman B, Varambally S, Cao X, Yu J, Helgeson $\mathrm{BE}$, et al. Role of the TMPRSS2-ERG gene fusion in prostate cancer. Neoplasia. 2008;10:177-88.

35. Nam RK, Sugar L, Yang W, Srivastava S, Klotz LH, Yang LY, et al. Expression of the TMPRSS2:ERG fusion gene predicts cancer recurrence after surgery for localised prostate cancer. $\mathrm{Br} \mathbf{J}$ Cancer. 2007;97:1690-5.

36. Spencer ES, Johnston RB, Gordon RR, Lucas JM, Ussakli CH, Hurtado-Coll A, et al. Prognostic value of ERG oncoprotein in prostate cancer recurrence and cause-specific mortality. Prostate. 2013;73:905-12.

37. Font-Tello A, Juanpere N, de Muga S, Lorenzo M, Lorente JA, Fumado L, et al. Association of ERG and TMPRSS2-ERG with grade, stage, and prognosis of prostate cancer is dependent on their expression levels. Prostate. 2015;75:1216-26.

38. Falzarano SM, Navas M, Simmerman K, Klein EA, Rubin MA, Zhou M, et al. ERG rearrangement is present in a subset of transition zone prostatic tumors. Mod Pathol. 2010;23:1499-506.

39. Minner S, Enodien M, Sirma H, Luebke AM, Krohn A, Mayer PS, et al. ERG status is unrelated to PSA recurrence in radically operated prostate cancer in the absence of antihormonal therapy. Clin Cancer Res. 2011;17:5878-88.

40. Hoogland AM, Jenster G, van Weerden WM, Trapman J, van der Kwast T, Roobol MJ, et al. ERG immunohistochemistry is not predictive for PSA recurrence, local recurrence or overall survival after radical prostatectomy for prostate cancer. Mod Pathol. 2012;25:471-9.

41. Bismar TA, Dolph M, Teng LH, Liu S, Donnelly B. ERG protein expression reflects hormonal treatment response and is associated with Gleason score and prostate cancer specific mortality. Eur J Cancer. 2012;48:538-46.

42. Toubaji A, Albadine R, Meeker AK, Isaacs WB, Lotan T, Haffner $\mathrm{MC}$, et al. Increased gene copy number of $E R G$ on chromosome 21 but not TMPRSS2-ERG fusion predicts outcome in prostatic adenocarcinomas. Mod Pathol. 2011;24:1511-20.

43. Cai C, Wang H, Xu Y, Chen S, Balk SP. Reactivation of androgen receptor-regulated TMPRSS2:ERG gene expression in castrationresistant prostate cancer. Cancer Res. 2009;69:6027-32.

44. Bonaccorsi L, Nesi G, Nuti F, Paglierani M, Krausz C, Masieri L, et al. Persistence of expression of the TMPRSS2:ERG fusion gene after pre-surgery androgen ablation may be associated with early PSA relapse of prostate cancer: preliminary results. J Endocrinol Invest. 2009;32:590-6.

45. Leinonen KA, Tolonen TT, Bracken H, Stenman UH, Tammela TL, Saramäki OR, et al. Association of SPINK1 expression and TMPRSS2:ERG fusion with prognosis in endocrine-treated prostate cancer. Clin Cancer Res. 2010;16:2845-51.

46. Boormans JL, Hermans KG, Made AC, van Leenders GJ, Wildhagen MF, Collette L, et al. Expression of the androgen-regulated fusion gene TMPRSS2-ERG does not predict response to endocrine treatment in hormone-naïve, node-positive prostate cancer. Eur Urol. 2010;57:830-5.

47. Danila DC, Anand A, Sung CC, Heller G, Leversha MA, Cao L, et al. TMPRSS2-ERG status in circulating tumor cells as a predictive biomarker of sensitivity in castration-resistant prostate cancer patients treated with abiraterone acetate. Eur Urol. 2011;60:897-904.

48. The Cancer Genome Atlas Research Network. The molecular taxonomy of primary prostate cancer. Cell. 2015;163:1011-25.

49. Gao J, Aksoy BA, Dogrusoz U, Dresdner G, Gross B, Sumer SO, et al. Integrative analysis of complex cancer genomics and clinical profiles using the cBioPortal. Sci Signal. 2013;6:pl1.

50. Cerami E, Gao J, Dogrusoz U, Gross BE, Sumer SO, Aksoy BA, et al. The cBio cancer genomics portal: an open platform for exploring multidimensional cancer genomics data. Cancer Discov. 2012;2:401-4.

51. Yu S, Xu Z, Zou C, Wu D, Wang Y, Yao X, et al. Ion channel TRPM8 promotes hypoxic growth of prostate cancer cells via an $\mathrm{O}_{2}$-independent and RACK1-mediated mechanism of HIF-1 $\alpha$ stabilization. J Pathol. 2014;234:514-25.

52. Yu S, Wang MW, Yao X, Chan FL. Establishment of a novel immortalized human prostatic epithelial cell line stably expressing androgen receptor and its application for the functional screening of androgen receptor modulators. Biochem Biophys Res Commun. 2009;382:756-61. 
53. Chu JH, Yu S, Hayward SW, Chan FL. Development of a threedimensional culture model of prostatic epithelial cells and its use for the study of epithelial-mesenchymal transition and inhibition of PI3K pathway in prostate cancer. Prostate. 2009;69:428-42.

54. Cai G, Wu D, Wang Z, Xu Z, Wong KB, Ng CF, et al. Collapsin response mediator protein-1 (CRMP1) acts as an invasion and metastasis suppressor of prostate cancer via its suppression of epithelial-mesenchymal transition and remodeling of actin cytoskeleton organization. Oncogene. 2017;36:546-58.

55. Yu S, Jia L, Zhang $\mathrm{Y}, \mathrm{Wu} \mathrm{D}, \mathrm{Xu} \mathrm{Z}, \mathrm{Ng} \mathrm{CF}$, et al. Increased expression of activated endothelial nitric oxide synthase contributes to antiandrogen resistance in prostate cancer cells by suppressing androgen receptor transactivation. Cancer Lett. 2013;328:83-94.

56. Yu S, Wong YC, Wang $\mathrm{XH}$, Ling MT, $\mathrm{Ng} \mathrm{CF}$, Chen $\mathrm{S}$, et al. Orphan nuclear receptor estrogen-related receptor- $\beta$ suppresses in vitro and in vivo growth of prostate cancer cells via $\mathrm{p} 21^{\mathrm{WAF} 1 /}$ CIP1 induction and as a potential therapeutic target in prostate cancer. Oncogene. 2008;27:3313-28.

57. Wang Q, Carroll JS, Brown M. Spatial and temporal recruitment of androgen receptor and its coactivators involves chromosomal looping and polymerase tracking. Mol Cell. 2005;19:631-42.

58. Wang Z, Wu D, Ng CF, Teoh JY, Yu S, Wang Y, et al. Nuclear receptor profiling in prostatospheroids and castration-resistant prostate cancer. Endocr Relat Cancer. 2018;25:35-50. 